CASSOWARY volume 2 (1): 49 - 67

ISSN : 2614-8900

E-ISSN : 2622-6545

CProgram Pascasarjana Universitas Papua, https://pasca.unipa.ac.id/

\title{
Analisis kawasan hutan dan tutupan hutan pada tiga daerah aliran sungai di Kabupaten Manokwari
}

\author{
Analysis of forest areas and forest cover in three rivers in Manokwari Regency \\ Haerul Arifin, Charlie D. Heatubun, Wahyudi* \\ Program Studi Ilmu Lingkungan, Program Pascasarjana UNIPA Manokwari \\ *Email: wahyudi.s.pono@gmail.com
}

\begin{abstract}
Law number 41 of 1999 concerning Forestry mandates to maintain the area of forest area and forest cover for each rivers at least $30 \%$ of the total area, with a proportional distribution. The purpose of this study was to determine the area and percentage of the area and forest cover in the three watersheds, Arui, Prafi, and Wosi, in Manokwari District, analyze the composition, distribution, and changes in the area and forest cover, and describe the factors that influence these changes. this uses descriptive methods with quantitative analysis techniques. Data collection and analysis is done spatially using ArcGIS / ArcMap 10.1 software. The research variables consisted of area and forest cover in the watershed, composition, distribution, and change in the area and forest cover, area of forest cover inside and outside the area expressed in hectares (ha) and percent (\%), as well as factors that influence changes in the area and forest cover. The results showed that until 2016, the percentage of forest area to the total watershed for the two watersheds (Arui and Prafi) was still above 30\%, while the Wosi watershed was only $14.79 \%$, but the percentage of forest cover for the three watersheds was still above 30\% The composition of the Arui and Prafi Watershed Forest Areas is dominated by Permanent Forests, whereas the Wosi Watershed is dominated by convertible Production Forests. In the Arui and Prafi watersheds, the distribution of the forest area is more concentrated in the upstream area and is dominated by primary forest, while the Wosi watershed is only in a portion of the upstream area with a predominance of secondary forest. During 2006 - 2016, the largest deforestation occurred in the Arui watershed $(4.71 \%$ at a rate of 121.80 ha / year), conversely the highest forest degradation occurred in the Wosi watershed (39\% at a rate of 5.31 ha / year). The dominant factor causing the change in the area in the three watersheds is thought to be a factor in partial change of forest area designation and Changes in Spatial Planning for the Provinces of West Papua and Manokwari in 2013-2033. Furthermore, population growth and land conversion to oil palm plantations, both by companies and communities, are the dominant factors causing deforestation.
\end{abstract}

Keywords: Rivers, forest, forest cover, deforestation, forest degradation

\begin{abstract}
ABSTRAK : Undang-Undang Nomor 41 Tahun 1999 tentang Kehutanan mengamanatkan untuk mempertahankan luas kawasan hutan dan penutupan hutan untuk setiap DAS minimal sebesar $30 \%$ dari total arealnya, dengan sebaran yang proporsional. Tujuan penelitian ini adalah mengetahui luas dan persentase kawasan dan
\end{abstract}


tutupan hutan pada tiga DAS, Arui, Prafi, dan Wosi, di Kabupaten Manokwari, menganalisis komposisi, distribusi, dan perubahan kawasan dan tutupan hutan, serta mendeskripsikan faktor-faktor yang mempengaruhi perubahan tersebut.Penelitian ini menggunakan metode deskriptif dengan teknik analisis kuantitatif.Pengumpulan dan Analisis data dilakukan secara spasial menggunakan perangkat lunak ArcGIS/ArcMap 10.1. Variabel penelitian terdiri dari luas kawasan dan tutupan hutan dalam DAS, komposisi, distribusi, dan perubahan kawasan dan tutupan hutan, luas tutupan hutan di dalam dan luar kawasan yang dinyatakan dalam hektar (ha) dan persen (\%), serta faktor yang mempengaruhi perubahan kawasan dan tutupan hutan. Hasil penelitian menunjukan bahwa sampai dengan tahun 2016, persentase luas kawasan hutan terhadap total DAS untuk dua DAS (Arui dan Prafi) masih di atas $30 \%$, sedangkan DAS Wosi hanya $14.79 \%$, akan tetapi persentase luas tutupan hutan untuk ketiga DAS tersebut masih di atas $30 \%$. Komposisi Kawasan Hutan DAS Arui dan Prafi didominasi oleh Hutan Tetap, sebaliknya DAS Wosi didominasi oleh Hutan Produksi yang dapat dikonversi. Pada DAS Arui dan Prafi, distribusi kawasan hutannya lebih terkonsentrasi pada daerah hulu dan didominasi oleh hutan primer, sedangkan DAS Wosi hanya pada sebagian daerah hulu dengan dominasi hutan sekunder. Selama Tahun 2006 - 2016, deforestasi terbesar terjadi pada DAS Arui (4.71 \% dengan laju 121,80 ha/tahun), sebaliknya degradasi hutan tertinggi terjadi pada DAS Wosi (39\% dengan laju 5.31 ha/tahun). Faktor dominan penyebab terjadinya perubahan kawasan pada tiga DAS tersebut diduga adalah faktor perubahan peruntukan kawasan hutan secara parsial dan Perubahan Rencana Tata Ruang Wilayah Provinsi Papua Barat dan Kabupaten Manokwari Tahun 2013-2033. Selanjutnya, pertambahan penduduk, dan konversi lahan menjadi areal perkebunan kelapa sawit, baik oleh perusahaan dan masyarakat, adalah faktor yang dominan penyebab deforestasi.

Kata Kunci: Daerah Aliran Sungai, Kawasan Hutan, Tutupan Hutan, Deforestasi, Degradasi Hutan

\section{PENDAHULUAN}

Undang-Undang Nomor 41 Tahun 1999 mengamanatkan bahwa pemerintah menetapkan dan mempertahankan kecukupan luas kawasan hutan dan penutupan hutan untuk setiap Daerah Aliran Sungai (DAS), dan atau pulau guna optimalisasi manfaat lingkungan, manfaat sosial, dan manfaat ekonomi masyarakat setempat minimal sebesar $30 \%$ (tiga puluh persen) dari luas Daerah Aliran Sungai dan atau pulau dengan sebaran yang proporsional. Mandat dari UndangUndang 41 Tahun 1999 tersebut sampai saat ini belum tercapai dan bahkan luas kawasan hutan dan juga tutupan hutan semakin menipis. Kerusakan (deforestasi dan degradasi hutan) tersebut menjadi penyebab terjadinya penurunan kualitas DAS. Sebagai akibatnya, kestabilan ekosistem terganggu dan menimbulkan dampak negatif terhadap peran hutan sebagai penyangga kehidupan termasuk dalam menjaga stabilitas tata air. Hal ini ditunjukkan dengan meningkatnya jumlah dan luas DAS yang dimasukkan ke dalam kategori yang harus dipulihkan atau dalam kondisi kritis (Maryani et al., 2014).

Sehubungan dengan kedudukan Kabupaten Manokwari sebagai Ibu Kota Provinsi Papua Barat, maka perkembangan wilayah terjadi dengan cepat. Kebutuhan akan ruang dan lahan akan mengarah pada penggunaan dan pemanfaatan hutan dan kawasan hutan. Dina- 
mika pemanfaatan lahan ini akan berkontribusi terhadap tutupan hutan baik dalam skala administrasi kabupaten dan tentunya dalam skala DAS. Pemanfaatan ruang/ lahan untuk pembangunan dan pengembangan wilayah mengakibatkan alih fungsi hutan menjadi penggunaan lain seperti pemukiman, pertanian, perkebunan dan penggunaan lain.

Selain itu penetapan SK.783/ Menhut-II/2014 tentang Kawasan Hutan dan Konservasi Perairan Provinsi Papua Barat berimplikasi pada perubahan luas dan fungsi kawasan hutan di Kabupaten Manokwari. Perubahan peruntukan kawasan hutan menjadi bukan kawasan hutan melalui proses pelepasan kawasan Hutan Produksi Konversi (HPK) menjadi Areal Penggunaan Lain (APL) untuk lahan perkebunan, pertanian, dan pemukiman dan kepentingan lain juga merupakan penyumbang terbesar berkurangnya luas kawasan hutan baik dalam skala kabupaten maupun skala DAS.

Agar fungsi hidrologis suatu ekosistem DAS dapat berfungsi dengan baik, maka salah satu faktor yang sangat penting adalah faktor vegetasi. Dalam konteks pengelolaan hutan, aspek vegetasi dapat dipenuhi dari indikasi kecukupan kawasan hutan dan tutupan hutan. Atas dasar hal tersebut maka pemerintah telah menetapkan angka kecukupan kawasan hutan dan tutupan hutan minimal sebesar $30 \%$ dari luasan DAS walaupun dari beberapa hasil penelitian luasan hutan optimal akan berbeda pada setiap DAS tergantung dengan karakteristik masingmasing DAS.

Berdasarkan data dari Balai Pengelolaaan DAS dan Hutan Lindung Remu-Ransiki (2014), terdapat 38 unit DAS di Kabupaten Manokwari yang terdiri dari kategori DAS yang dipertahankan daya dukungnya dan DAS yang dipulihkan daya dukungnya. DAS dengan Klasifikasi Dipulihkan Daya Dukungnya terdiri dari DAS Aipiri, DAS
Arui, DAS Prafi, DAS Warmare, DAS Pami, DAS Wosi dan DAS Batusini (BPDAS Remu Ransiki, 2014). Dari 7 (tujuh) DAS dengan kategori dipulihkan daya dukungnya tersebut, DAS Arui, DAS Prafi dan DAS Wosi merupakan DAS yang terindikasi mengalami penurunan fungsi hidrologis. Hal ini dapat terindikasi dengan bertambahnya pusat-pusat pemukiman penduduk, pusat pemerintahan, dan lahan pertanian sebagai akibat dari kebijakan pengembangan wilayah sehingga berdampak pada meningkatnya kejadian banjir di daerah-daerah yang berada di dalam ketiga DAS tersebut pada beberapa tahun terakhir. Sampai dengan saat ini data dan informasi mengenai kondisi kawasan hutan dan tutupan hutan pada Tiga DAS, Arui, Prafi, dan Wosi di Kabupaten Manokwari belum banyak dikaji lebih mendalam untuk dapat digunakan dalam perencanaan pengelolaan lebih lanjut.

Tujuan penelitian ini adalah untuk mengetahui luas dan persentase kawasan dan tutupan hutan pada tiga DAS, Arui, Prafi, dan Wosi; menganalisis komposisi dan distribusi kawasan dan tutupan hutan pada tiga DAS, Arui, Prafi, dan Wosi; Menganalisis perubahan tutupan hutan pada tiga DAS, Arui, Prafi, dan Wosi, Mendeskripsikan faktor-faktor yang mempengaruhi perubahan kawasan dan tutupan hutan pada tiga DAS, Arui, Prafi, dan Wosi.

\section{METODE}

Penelitian ini menggunakan data sekunder berupa Peta DAS di Kabupaten Manokwari, Data dan Peta Kawasan Hutan Kabupaten Manokwari Skala 1:250.000 Tahun 2006 dan 2016 (Lampiran SK.891/Menhutbun-II/1999 dan SK.783/Menhut-II/2014), Data dan Peta Tutupan Lahan (Land Cover) Kabupaten Manokwari Skala 1:250,000 Tahun 2006, 2009, 2012, 2015, dan 2016. 
Survey lapangan (ground chek) dilakukan secara purposive pada beberapa titik yang mengalami perubahan tutupan lahan untuk mendukung hasil analisis data sekunder. Peralatan yang digunakan dalam penelitian ini berupa perangkat lunak SIG ArcGIS/ArcMap versi 10.1. Variabel yang diukur dalam penelitian ini terdiri dari luas kawasan dan tutupan hutan dalam DAS dalam satuan hektar (ha) dan persen (\%), komposisi dan distribusi kawasan dan tutupan hutan dalam DAS dalam satuan hektar (ha) dan persen (\%), dan perubahan tutupan hutan (deforestasi dan degradasi hutan) dalam satuan hektar (ha) dan persen (\%), serta faktor yang mempengaruhi perubahan kawasan dan tutupan hutan.

Analisis data dilakukan secara spasial dengan teknik Overlay (tumpang susun) menggunakan aplikasi Sistem Informasi Geografis (SIG) dengan perangkat lunak ArcGIS/ArcMap 10.1, kemudian dilakukan perhitungan persentase kawasan hutan dan tutupan hutan. Perhitungan perubahan tutupan hutan (deforestasi) merujuk pada Kementerian Lingkungan Hidup dan Kehutanan, (2015) yaitu dengan menghitung luas tutupan hutan Tahun 2006 yang mengalami perubahan menjadi non hutan di Tahun 2016 atau Tutupan Hutan Tahun 2006 Tutupann Hutan Tahun 2016, sedangkan degradasi hutan diketahui dengan menghitung luas tutupan hutan primer pada Tahun 2006 yang mengalami perubahan menjadi hutan sekunder di Tahun 2006. Hasil analisis selanjutnya ditampilkan dalam tabulasi, diagram, grafik dan peta. Faktor-faktor yang berpengaruh terhadap perubahan kawasan hutan dan tutupan hutan dideskripsikan berdasarkan kajian pustaka yang relevan.

Perhitungan-perhitungan analisis sebagai berikut:

\section{Presentase Kawasan Hutan dalam DAS}

$\%$ Kawasan Hutan $=\quad$ Luas Kawasan Hutan dalam DAS (ha) $\quad$ x $100 \%$ Luas DAS (ha)

\section{Presentase Tutupan Hutan dalam DAS}

Terdiri dari persentase total tutupan hutan dalam DAS, persentase tutupan hutan dalam kawasan hutan dan persentase tutupan hutan di luar kawasan hutan

$\%$ Tutupan Hutan $=\frac{\text { Luas Tutupan Hutan dalam DAS (ha) }}{\text { Luas DAS (ha) }} \times 100 \%$

\begin{tabular}{|c|c|c|c|}
\hline \multirow{2}{*}{\multicolumn{3}{|c|}{$\begin{array}{l}\text { \% Tutupan Hutan dalam } \\
\text { Kawasan Hutan DAS }\end{array}$}} & Luas Tutupan Hutan dalam \\
\hline & & & Kawasan Hutan DAS (ha) \\
\hline$=$ & & & Luas DAS (ha) \\
\hline
\end{tabular}

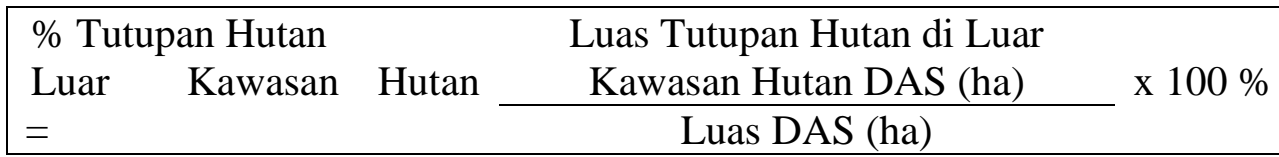




Presentase Komposisi Kawasan Hutan dalam DAS
\begin{tabular}{|lcc|}
$\%$ Komposisi & Kawasan & Luas Fungsi Kawasan Hutan dalam \\
Hutan $=$ & DAS (ha) & \\
\cline { 2 - 3 } & & Luas DAS (ha) \\
\hline
\end{tabular}

Keterangan: Fungsi Kawasan Hutan terdiri dari Hutan Konservasi, Hutan Lindung, Hutan Produksi Terbatas, Hutan Produksi, dan Hutan Produksi yang dapat diKonversi

> Presentase Komposisi Tutupan Hutan dalam DAS
\begin{tabular}{|lccc|}
\hline$\%$ Komposisi Tutupan Hutan & Luas Kategori Tutupan Hutan dalam & x & 100 \\
\cline { 2 - 3 } & DAS (ha) & $\%$ & \\
\hline
\end{tabular}

Keterangan: Kategori Tutupan Hutan terdiri dari Hutan Primer dan Hutan Sekunder

\section{Deforestasi}

Deforestasi $=$ Tutupan Hutan $\mathrm{t}_{0}(\mathrm{ha})$ - Tutupan Hutan $\mathrm{t}_{\mathrm{n}}(\mathrm{ha})$

Keterangan: $\mathrm{t}_{0}=$ Tahun ke- $0 ; \mathrm{t}_{\mathrm{n}}=$ Tahun ke-n

HASIL DAN PEMBAHASAN

\section{Luas Kawasan Hutan}

Tabel 1. menjelaskan bahwa sampai dengan Tahun 2014, luas kawasan hutan pada ketiga DAS di Kabupaten Manokwari masih di atas 30 $\%$, dengan persentase tertinggi terdapat pada DAS Prafi (81.74\%). Sebaliknya setelah Tahun 2014, terjadi penurunan persentase luas kawasan hutan dengan penurunan tertinggi terjadi pada DAS Wosi $(17.25 \%)$ yang mengakibatkan luas kawasan hutan berkurang dari $32.04 \%$ di Tahun 2006 menjadi 14.79 $\%$ di Tahun 2016. Kondisi ini menunjukan bahwa persentase luas kawasan hutan DAS Arui dan DAS Prafi Tahun 2016 masih memenuhi persyaratan kecukupan kawasan hutan sebesar minimal $30 \%$ sebagaimana ditentukan dalam Undang-Undang nomor 41 Tahun 1999 tentang Kehutanan sedangkan persentase luas kawasan hutan di DAS Wosi hanya tersisa 14.79 $\%$, dengan demikian tidak memenuhi ketentuan kecukupan kawasan hutan yang ditentukan.
Kawasan hutan adalah wilayah tertentu yang ditunjuk dan/atau ditetapkan oleh pemerintah untuk dipertahankan keberadaannya sebagai hutan tetap. Penunjukan atau Penetapan Kawasan Hutan merupakan aspek penting dalam pengelolaan hutan karena merupakan aspek legal yang akan menjamin kepastian hukum dalam pengelolaan hutan. Sesuai Peraturan Pemerintah Nomor 44 Tahun 2004 tentang Sistem Perencanaan Kehutanan, keberadaan kawasan hutan tersebut merupakan hasil dari proses pengukuhan kawasan hutan, yang meliputi tahapan mulai dari penunjukan kawasan hutan, penataan batas kawasan hutan, pemetaan kawasan hutan dan penetapan kawasan hutan. Tingkatan-tingkatan tersebut mengandung konsekuensi hukum, sehingga secara de jure kawasan hutan akan ada setelah suatu kawasan minimal ditunjuk oleh Menteri Kehutanan sebagai kawasan hutan termasuk batasbatasnya walaupun batas tersebut masih di atas peta (Iskandar, et al 2011). 
Tabel 1.Luas dan Persentase Kawasan Hutan pada Tiga DAS, Arui, Prafi, dan Wosi

\section{Kawasan Hutan}

\begin{tabular}{|c|c|c|c|c|c|}
\hline \multirow[t]{2}{*}{ DAS } & \multirow{2}{*}{$\begin{array}{c}\text { Luas DAS } \\
\text { (ha) }\end{array}$} & \multicolumn{2}{|c|}{ Luas (ha) } & \multicolumn{2}{|c|}{ Persen (\%) } \\
\hline & & $\begin{array}{c}\text { Thn } 2006 * \text { ) } \\
(\text { SK.891/ 1999) }\end{array}$ & $\begin{array}{l}\text { Tahun } 2016 * *) \\
(\text { SK.783/ 2014) }\end{array}$ & $\begin{array}{c}\text { Thn 2006*) } \\
(\text { SK.891/ 1999) }\end{array}$ & $\begin{array}{c}\text { Tahun } 2016 * *) \\
(\text { SK.783/2014) }\end{array}$ \\
\hline Arui & $23,235.23$ & $14,067.86$ & $11,454.52$ & 60.55 & 49.30 \\
\hline Prafi & $67,557.96$ & $55,220.30$ & $48,386.12$ & 81.74 & 71.62 \\
\hline Wosi & $2,346.32$ & 751.75 & 347.13 & 32.04 & 14.79 \\
\hline$*)$ & 1012 & $9-2014$ & & & \\
\hline$* *)$ & : Tahun 2 & $14-2016$ & & & \\
\hline
\end{tabular}

\section{Luas Tutupan Hutan}

Tabel 2. Luas dan Persentase Tutupan Hutan pada Tiga DAS, Arui, Prafi, dan Wosi

\begin{tabular}{lcrrrr}
\hline & & \multicolumn{4}{c}{ Tutupan Hutan } \\
\cline { 3 - 6 } \multicolumn{1}{c}{ DAS } & Luas DAS & \multicolumn{2}{c}{ Luas (ha) } & \multicolumn{2}{c}{ Persentase (\%) } \\
\cline { 3 - 6 } & (ha) & Thn 2006 & Tahun 2016 & Thn 2006 & Tahun 2016 \\
\hline Arui & $23,235.23$ & $12,826.48$ & $11,730.93$ & 55.20 & 50.49 \\
Prafi & $67,557.96$ & $49,004.03$ & $47,785.98$ & 72.54 & 70.73 \\
Wosi & $2,346.32$ & 962.09 & 930.52 & 41.00 & 39.66 \\
\hline
\end{tabular}

Tabel 3. Komposisi Kawasan Hutan pada Tiga DAS, Arui, Prafi, dan Wosi

\begin{tabular}{|c|c|c|c|c|c|c|}
\hline \multirow[b]{2}{*}{ Fungsi Kawasan } & \multicolumn{2}{|c|}{ DAS Arui } & \multicolumn{2}{|c|}{ DAS Prafi } & \multicolumn{2}{|l|}{ DAS Wosi } \\
\hline & $\begin{array}{c}\text { Thn } 2006 \\
\text { (ha) }\end{array}$ & $\begin{array}{c}\text { Thn } 2016 \\
\text { (ha) }\end{array}$ & $\begin{array}{c}\text { Thn } 2006 \\
\text { (ha) }\end{array}$ & $\begin{array}{c}\text { Thn } 2016 \\
\text { (ha) }\end{array}$ & $\begin{array}{c}\text { Thn } 200 \\
\text { (ha) }\end{array}$ & $\begin{array}{c}\text { Thn } 2016 \\
\text { (ha) }\end{array}$ \\
\hline Kawasan Hutan & $14,067.86$ & $11,454.52$ & $55,220.30$ & $48,386.12$ & 751.75 & 347.13 \\
\hline Hutan Konservasi & 215.98 & 4.46 & $7,941.34$ & $8,344.43$ & - & - \\
\hline Hutan Lindung & 182.07 & 182.07 & $19,179.96$ & $19,487.25$ & - & - \\
\hline Hutan Produksi & 9.830 .24 & $9,066.09$ & $17,331.30$ & $14,327.98$ & - & - \\
\hline Terbatas & & & & & & \\
\hline Hutan Produksi Tetap & - & - & $4,099.20$ & $4,043.32$ & - & - \\
\hline Hutan Produksi & $3,839.57$ & $2,201.90$ & $6,668.50$ & $2,183.14$ & 751.75 & 347.13 \\
\hline Konversi & & & & & & \\
\hline $\begin{array}{l}\text { Areal Penggunaan } \\
\text { Lain }\end{array}$ & $9,134.09$ & $11,747.42$ & $12,060.86$ & $18,895.04$ & $1,594.56$ & $1,999.19$ \\
\hline Tubuh Air & 33.29 & 33.29 & 276.80 & 276.80 & - & \\
\hline Total & $23,235.23$ & $23,235.23$ & $67,557.96$ & $67,557.96$ & $2,346.32$ & $2,346.32$ \\
\hline
\end{tabular}

Tabel 2. mejelaskan bahwa persentase luas tutupan hutan pada tiga DAS di Kabupaten Manokwari pada Tahun 2006 masih di atas $30 \%$ dengan persentase tertinggi pada DAS Prafi (72.54 \%), diikuti DAS Arui $(55.20 \%)$, dan yang terkecil pada DAS Wosi (41.00 $\%)$. Pada Tahun 2016 persentase luas tutupan hutan cenderung menurun tetapi masih di atas $30 \%$. Penurunan terbesar terjadi pada DAS Arui ( $4.71 \%$ ), diikuti DAS Prafi $(1.81 \%)$, dan DAS Wosi
(1.34 \%). Persentase tutupan hutan ketiga DAS Tahun 2016 masih memenuhi ketentuan kecukupan luas tutupan hutan dalam wilayah DAS sebesar $30 \%$ sebagaimana diatur dalam ketentuan Pasal 18 Ayat (1) dan Ayat (2) Undang-Undang Nomor 41 Tahun 1999 tentang Kehutanan. Jika dibandingkan dengan hasil kajian Maryani, et al (2014) pada beberapa DAS yang dipulihkan daya dukungnya di Jawa dan Sumatera, maka persentase tutupan hutan di ketiga 
DAS ini masih lebih baik. Hasil kajian pada DAS Asahan, Sumatera Utara persentase tutupan hutan $24,25 \%$ DAS Baturusa, Bangka Belitung 2,13\%, DAS Tulang Bawang, Lampung 2,79\% dan DAS Ciliwung, Jawa Barat 9,5\%. Kajian yang dilakukan Kadir, (2013), pada DAS Satui Kalimantan Selatan bahwa persentase Tutupan Hutan yang tersisa sebesar $32 \%$ dari luas DAS.

Data pada Tabel 4.2. memperlihatkan bahwa dibandingkan DAS Arui dan DAS Prafi, DAS Wosi memiliki kerentanan tutupan hutan yang mengkhawatirkan karena mendekati am-bang batas ketentuan kecukupan tutupan yang dapat melindungi fungsi hidrolo-gisnya. Kondisi ini diperparah dengan rusaknya hutan pada sebagian daerah hulu DAS yang mengalami perubahan menjadi pusat-pusat pemukiman dan perdagangan. Kerusa-kan tutupan hutan pada sebagian daerah hulu DAS Wosi ini dapat merupakan salah satu faktor penyebab mening-katnya kejadian banjir di daerah hilir DAS. Berdasarkan data Balai Pengelo-laan DAS dan Hutan Lindung Remu Ransiki 2016, frekuensi kejadian banjir di DAS Wosi dalam kategori sangat tinggi dengan frekuensi lebih dari 1 kali kejadian dalam 1 tahun

\section{Komposisi dan Distribusi Kawasan Hutan}

Tabel 3. menjelaskan bahwa pada Tahun 2016 setelah ditetapkannnya SK. Nomor: 783/Menhut-II/2014, DAS Arui didominasi oleh Hutan Produksi Terbatas dengan luas 9,006.09 hektar (39.02 \%), DAS Prafi didominasi oleh Hutan Lindung dengan luas 19,487.25 hektar $(28.85 \%)$, sedangkan DAS Wosi hanya terdiri dari Hutan Produksi yang dapat diKonversi dengan luas 347.13 hektar (14.79\%). Jika dibandingkan dengan Tahun 2006 sesuai SK. Nomor: 891/Menhutbun-II/1999, persentase luas masing-masing fungsi kawasan hutan tersebut mengalami perubahan. Pada DAS Arui, Hutan Produksi Terbatas berkurang sebesar $3.29 \%$ menjadi 39.02 $\%$. Pada DAS Prafi, Hutan Lindung bertambah sebesar $0.46 \%$ menjadi 28.85 $\%$ dan Hutan Produksi Terbatas berkurang sebesar $4.44 \%$ menjadi 25.65 $\%$. Pada DAS Wosi terjadi pengurangan Hutan Produksi yang dapat diKonversi sebesar $17.25 \%$ menjadi tersisa 14.79 $\%$.

Dari ketiga DAS tersebut, DAS Wosi memiliki kerentanan terhadap perubahan peruntukan kawasan hutan menjadi bukan kawasan hutan melalui pelepasan Hutan Produksi yang dapat dikonversi menjadi Bukan Kawasan Hutan atau Areal Penggunaan Lain. Keadaan tersebut dapat terjadi karena secara de jure perubahan peruntukan kawasan Hutan Produksi yang dapat dikonversi menjadi Areal Penggunaan Lain dapat dilakukan sesuai dengan kebutuhan pembangunan daerah.

Hal ini bisa saja akan menjadi kebijakan Pemerintah Daerah Kabupaten Manokwari untuk mengakomodir kebutuhan ruang untuk pengembangan kota dan pusat-pusat pemukiman. DAS Wosi meliputi Distrik Manokwari Barat dan Distrik Manokwari Selatan yang merupakan pusat wilayah pemerintahan dan perkotaan Kabupaten Manokwari sehingga kebutuhan akan ruang dan lahan untuk pengembangan wilayah dan pembangunan daerah sangat tinggi. Ancaman terhadap DAS Wosi ini seiring dengan jumlah penduduk pada kedua distrik tersebut yang mengalami pertumbuhan yang pesat.

Distribusi Spasial Fungsi Kawasan Hutan pada Tiga DAS di Kabupaten Manokwari dapat dilihat pada Lampiran. Secara umum distribusi spasial kawasan hutan pada ketiga DAS tersebut terkonsentrasi pada daerah hulu DAS. Distribusi Kawasan Hutan pada daerah 
hulu DAS Arui terdiri dari Hutan Lindung dan Hutan Produksi Terbatas dengan luas 9,248.16 hektar (39.80\%). Distribusi Kawasan Hutan pada daerah hulu DAS Prafi terdiri dari Hutan Konservasi, Hutan Lindung, Hutan Produksi Terbatas, dan Hutan Produksi Tetap dengan luas 46,202.98 hektar (68.39 \%). Distribusi Kawasan Hutan pada sebagian daerah hulu DAS Wosi terdiri dari Hutan Produksi yang dapat diKonversi dengan luas 347.13 hektar (14.79 \%) Distribusi Spasial Kawasan Hutan pada DAS Arui, Prafi, dan Wosi dapat dilihat pada Lampiran 1.

Daerah hulu DAS merupakan zona penting dalam menjaga fungsi hidrologis karena merupakan zona perlindungan DAS. Hulu DAS merupakan zona konservasi yang dicirikan dengan kerapatan drainase yang tinggi, kemiringan lereng di atas 15 $\%$, dan vegetasi didominasi oleh tegakan hutan (Asdak, 2014). Adanya kawasan hutan pada daerah hulu DAS akan memberikan kepastian hukum dalam pengelolaan hutan terutama aspek perlindungan dan pelestarian hutan di daerah hulu tersebut. Hutan yang berada dalam suatu kawasan hutan secara de jure akan lebih terjaga dan terlindungi keberadaanya dibandingkan hutan yang berada di luar kawasan hutan atau di Areal Penggunaan Lain.

\section{Komposisi dan Distribusi Tutupan Hutan}

Tabel 4 menjelaskan pada Tahun 2016, Tutupan Hutan DAS Arui didominasi oleh Hutan Primer dengan luas 7,979.35 hektar (34.34 \%), DAS Prafi didominasi oleh Hutan Primer dengan luas 37.583 hektar (55.63\%) sedangkan DAS Wosi didominasi oleh Hutan Sekunder dengan luas 847.37 hektar $(36.11 \%)$ dari luas DAS. Jika dibandingkan dengan keadaaan Tahun 2006, persentase tersebut cenderung mengalami penurunan kecuali pada DAS Wosi. Pada DAS Arui persentase luas Hutan Primer berkurang sebesar $4.43 \%$ menjadi $38.77 \%$, DAS Prafi berkurang sebesar $1.82 \%$ menjadi $55.63 \%$, sedangkan pada DAS Wosi persentase luas Hutan Sekunder menjadi bertambah sebesar $0.91 \%$ menjadi $36.11 \%$ sedang persentase Hutan Primer berkurang sebesar $2.27 \%$ dari $5.81 \%$ menjadi 3.54 $\%$.

Tabel 4. Komposisi Tutupan Hutan pada Tiga DAS, Arui, Prafi, dan Wosi

\begin{tabular}{lrrrrrr}
\hline \multirow{3}{*}{ Tutupan Hutan } & \multicolumn{2}{c}{ DAS Arui } & \multicolumn{2}{c}{ DAS Prafi } & \multicolumn{2}{c}{ DAS Wosi } \\
\cline { 2 - 7 } & Thn 2006 & Thn 2016 & Thn 2006 & \multicolumn{1}{c}{ Thn 2016 } & Thn 2006 & \multicolumn{1}{c}{ Thn 2016 } \\
& Luas (ha) & Luas (ha) & Luas (ha) & Luas (ha) & Luas (ha) & Luas (ha) \\
\hline Hutan Primer & $\mathbf{9 , 0 0 9 . 1 8}$ & $\mathbf{7 , 9 7 9 . 3 5}$ & $\mathbf{3 8 , 8 1 0 . 6 7}$ & $\mathbf{3 7 , 5 8 3 . 4}$ & $\mathbf{1 3 6 . 2 9}$ & $\mathbf{5 . 8 1}$ \\
HLKP & $7,812.37$ & $7,192.41$ & $38,722.41$ & $37,535.07$ & 136.29 & 5.81 \\
HRP & $1,196.81$ & 786.94 & 86.16 & 48.33 & - & - \\
HMP & - & - & 2.1 & - & - & \\
Hutan Sekunder & $\mathbf{3 , 8 1 7 . 3 0}$ & $\mathbf{3 , 7 5 1 . 5 8}$ & $\mathbf{1 0 , 1 9 3 . 3 6}$ & $\mathbf{1 0 , 2 0 2 . 5 8}$ & $\mathbf{8 2 5 . 8 0}$ & $\mathbf{3 5 . 2 0}$ \\
HLKS & $3,817.30$ & $3,341.71$ & $10,046.31$ & $10,144.06$ & 825.80 & 35.20 \\
HRS & - & 409.87 & 25.13 & 58.52 & - & - \\
HMS & - & & 121.92 & - & - & - \\
\hline Tutupan Hutan & $\mathbf{1 2 , 8 2 6 . 4 8}$ & $\mathbf{1 1 , 7 3 0 . 9 3}$ & $\mathbf{4 9 , 0 0 4 . 0 3}$ & $\mathbf{4 7 , 7 8 5 . 9 8}$ & $\mathbf{9 6 2 . 0 9}$ & $\mathbf{9 3 0 . 5 2}$ \\
\hline
\end{tabular}

HLKP : Hutan Lahan Kering Primer, HRP : Hutan Rawa Primer, HMP : Hutan

Mangrove Primer, HLKS : Hutan Lahan Kering Sekunder, HRS : Hutan Rawa

Sekunder, HMS : Hutan Mangrove Sekunder 
Selain komposisi tutupan hutan, distribusi tutupan hutan dalam DAS juga merupakan aspek penting yang terkait dengan fungsi hidrologis dari hutan sebagai pengatur tata air. Distribusi spasial tutupan hutan di DAS Arui DAS Prafi dan DAS Wosi dapat dilihat pada Lampiran 2. Secara umum distribusi spasial tutupan hutan pada ketiga DAS tersebut terkonsentrasi pada daerah hulu DAS. Luas Tutupan Hutan yang berada pada daerah hulu DAS Arui sebesar 7,506.79 hektar (32.31\%), daerah hulu DAS Prafi 42,420.63 hektar (62.79\%), dan sebagian daerah hulu DAS Wosi 930.52 hektar (39.65 \%). Distribusi Spasial Tutupan Hutan pada DAS Arui, Prafi, dan Wosi dapat dilihat pada Lampiran 2.

Hasil tumpang susun (over lay) dengan Peta Kawasan Hutan, terlihat bahwa distribusi tutupan hutan pada daerah hulu DAS Arui tersebut berada dalam Kawasan Hutan Lindung dan Hutan Produksi Terbatas. Distribusi Tutupan Hutan pada daerah hulu DAS Prafi berada pada Kawasan Hutan Konservasi, Hutan Lindung, Hutan Produksi Terbatas, dan Hutan Produksi., sedangkan seluruh tutupan hutan di DAS Wosi yang berada pada sebagian daerah hulu DAS berada pada pada Kawasan Hutan yang dapat diKonversi. Secara keseluruhan pada ketiga DAS tersebut, persentase tutupan hutan yang berada pada daerah hulu DAS mempunyai korelasi yang positif dengan persentase distribusi kawasan hutan yang berada pada daerah hulu DAS. DAS Prafi memiliki persentase tutupan hutan pada daerah hulu DAS tertinggi (62.79\%) karena pada daerah hulu tersebut terdapat Hutan Konservasi dan Hutan Lindung yang merupakan kawasan hutan dengan fungsi konservasi dan perlindungan sehingga hutan pada zona ini lebih terjaga. Selain itu juga didukung dengan kondisi topografi
Hutan Konservasi dan Hutan Lindung yang lebih curam sehingga merupakan daerah dengan akesibilitas yang rendah.

Hasil analisis lebih jauh untuk melihat distribusi tutupan hutan di dalam dan di luar kawasan hutan pada ketiga DAS Tahun 2016 dapat dilihat pada Gambar 2.

Gambar 2 memperlihatkan bahwa distribusi tutupan hutan di dalam kawasan hutan dengan persentase terbesar terdapat di DAS Prafi (63.63 $\%$ ), kemudian diikuti oleh DAS Arui (38.47\%), dan yang terkecil DAS Wosi $(14.12 \%)$. Tutupan hutan yang terdistribusi dalam kawasan hutan relative akan lebih terjaga dan terlindungi dari perubahan untuk peruntukan lain (deforestasi). Secara de jure suatu kawasan hutan akan lebih memberikan kepastian hukum dalam pengelolaan hutan terutama dari aspek perlindungan dan pengaman hutan di bandingkan dengan bukan kawasan hutan (Areal Penggunaan Lain). Hutan yang berada di luar kawasan hutan atau berada dalam Areal Penggunaan Lain akan rentan terhadap deforestasi akibat peruntukan lain. Hal ini dimungkinkan karena secara keruangan Areal Penggunaan Lain memang diperuntukan untuk kepentingan pengembangan wilayah dan pembangunan daerah atau kepentingan lainnya.

\section{Perubahan Tutupan Hutan pada Tiga DAS, Arui, Prafi, dan Wosi Deforestasi}

Gambar 3 menjelaskan bahwa tutupan hutan DAS Arui mengalami penurunan sejak Tahun 2006. Penurunan tertinggi terjadi pada Tahun 2012 yang berkurang sebesar $2.98 \%$ dibandingkan Tahun 2009. Kontribusi terbesar pengurangan tutupan hutann pada periode ini disebabkan terjadinya pembukaan hutan menjadi Lahan Terbuka yang diper- 
siapkan sebagai lahan perkebunan kelapa sawit milik warga setempat. Selain itu juga pengurangan tutupan hutan tersebut disebabkan oleh perubahan tutupan hutan menjadi Semak Belukar yang kemungkinan dipersiapkan untuk lahan pertanian atau pemukiman.

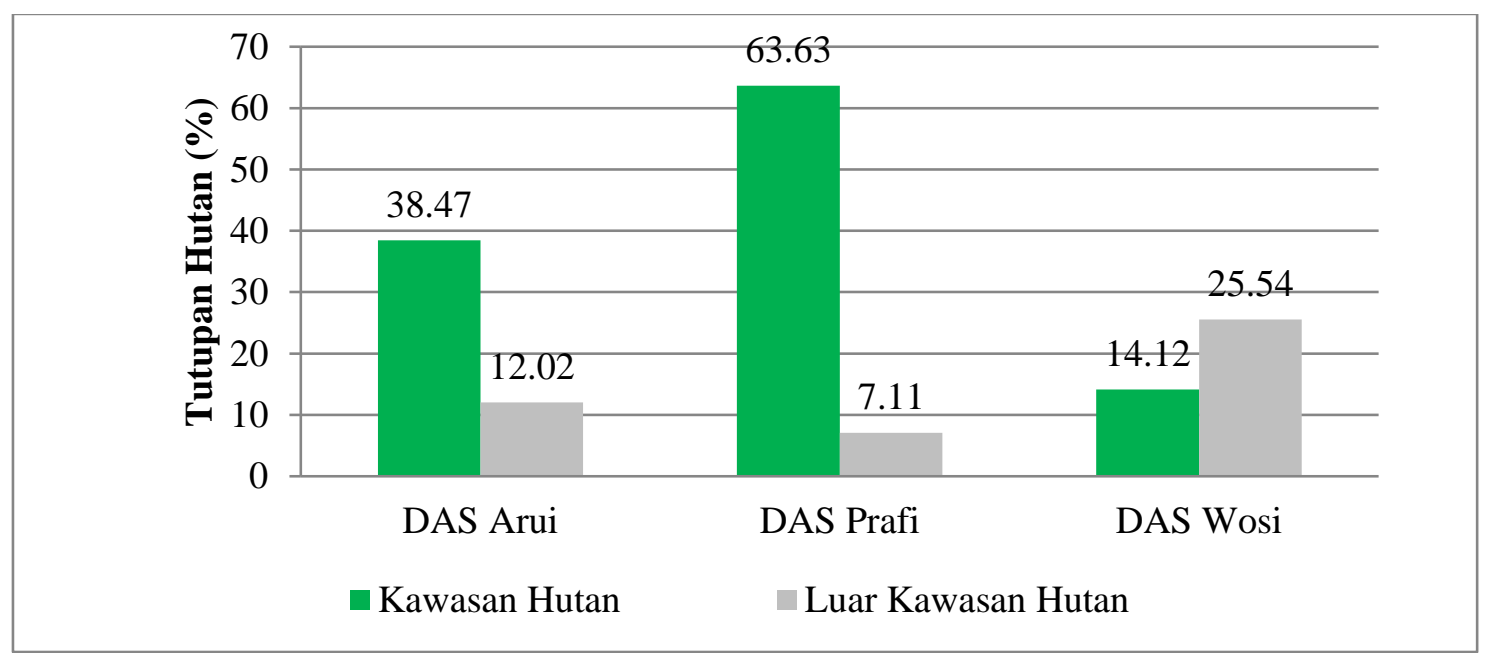

Gambar 2. Distribusi Tutupan Hutan di Dalam dan Luar Kawasan Hutan

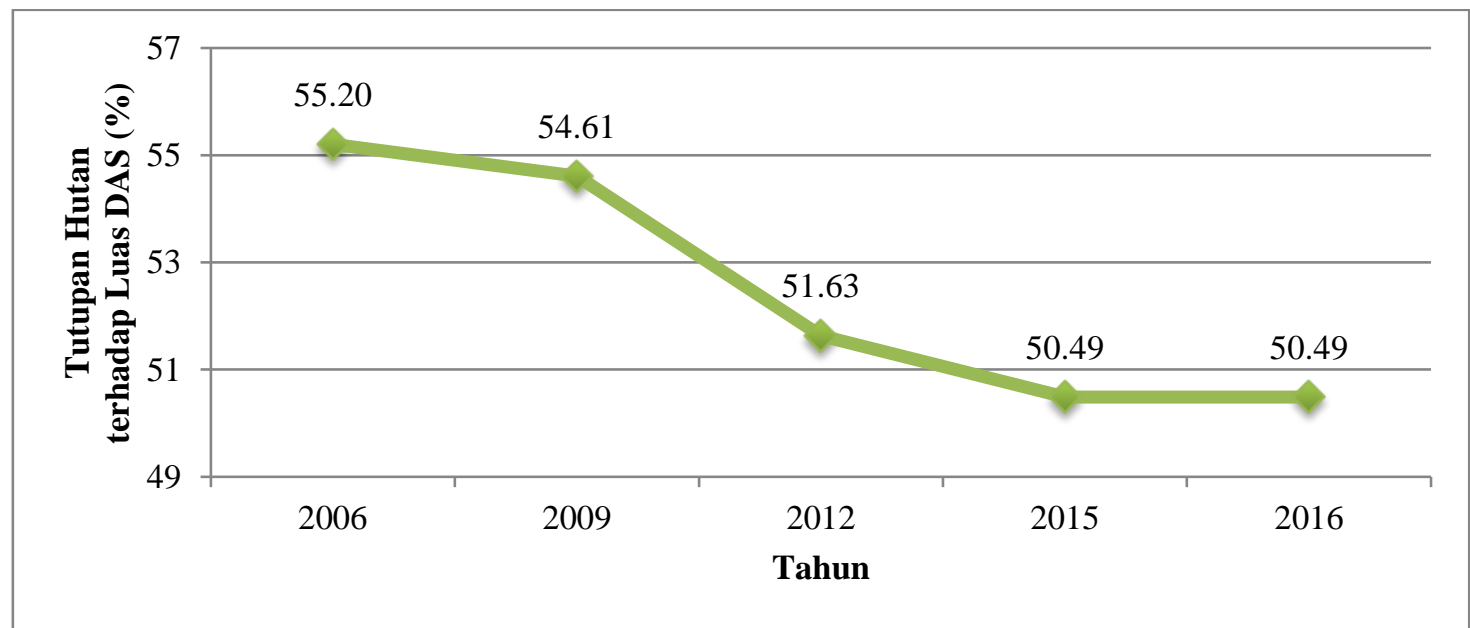

Gambar 3. Grafik Deforestasi pada DAS Arui

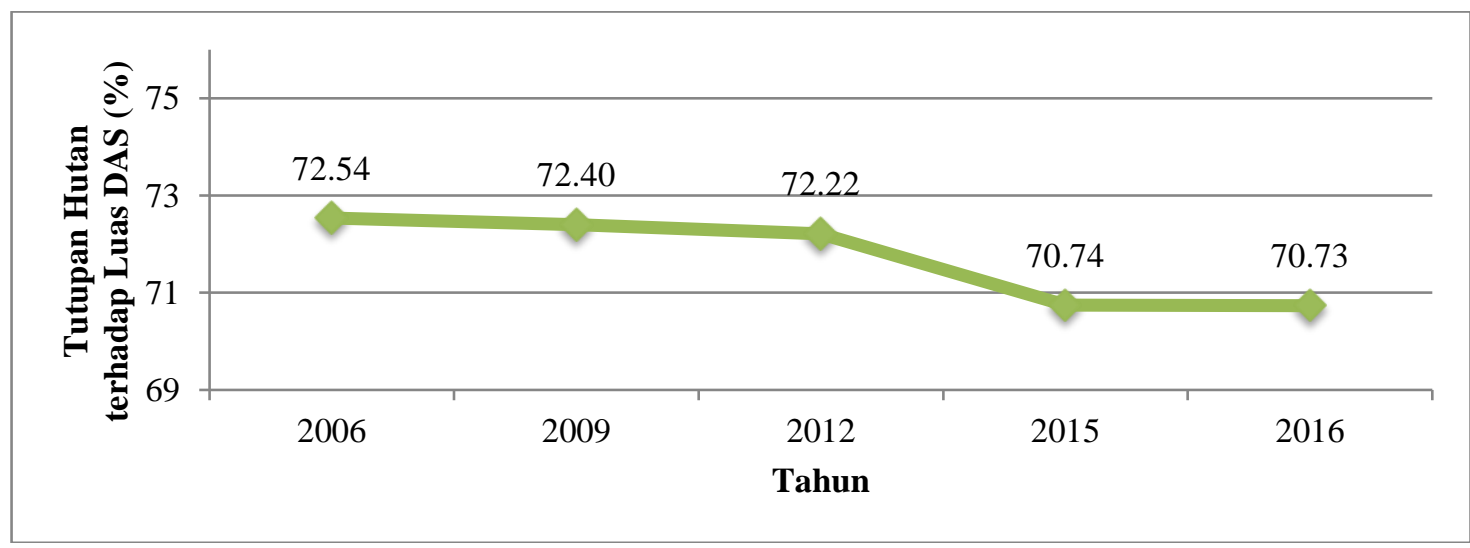

Gambar 4. Grafik Deforestasi pada DAS Prafi 


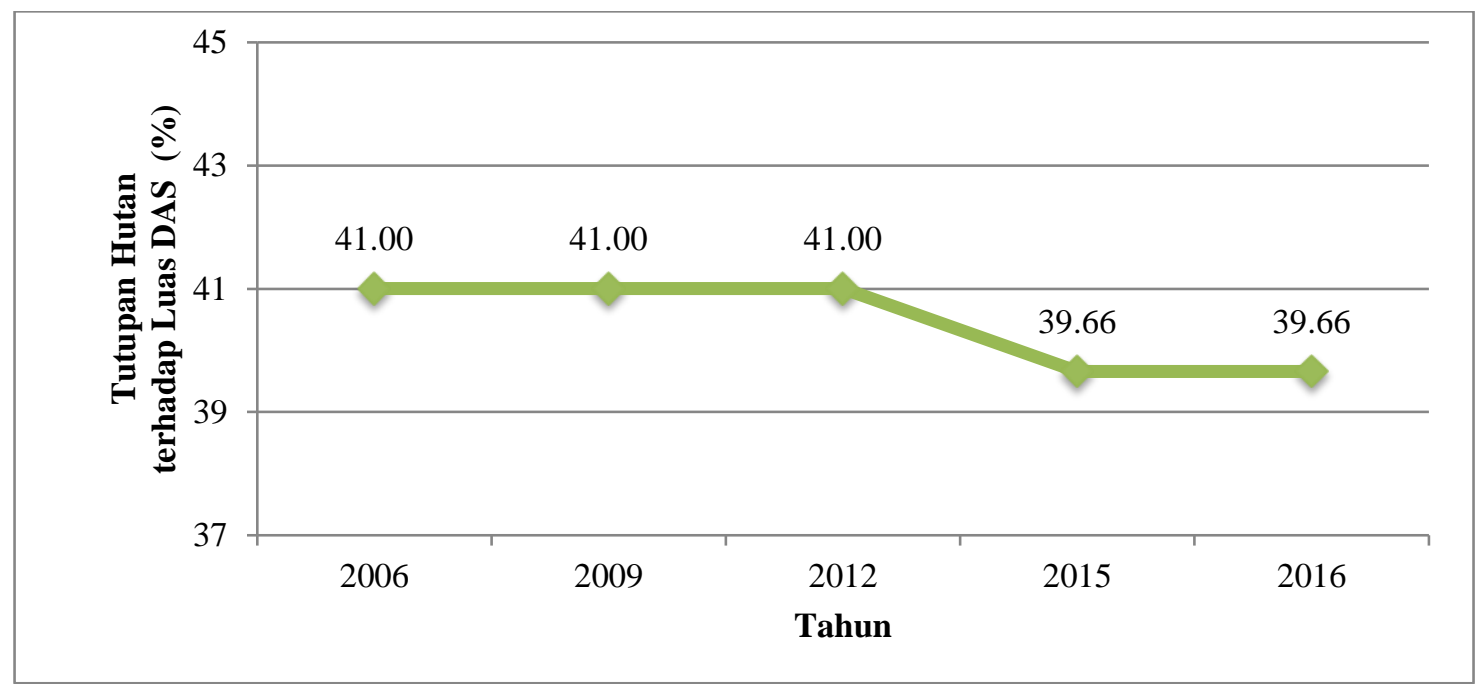

Gambar 5 Grafik Deforestasi DAS Wosi

Gambar 4 menjelaskan bahwa tutupan hutan DAS Prafi mengalami penurunan sejak Tahun 2006. Penurunan tertinggi terjadi pada Tahun 2015 yang berkurang sebesar $1.48 \%$ dibandingkan Tahun 2012. Kontribusi terbesar pengurangan tutupan hutan pada periode ini disebabkan terjadinya pembukaan hutan menjadi areal perkebunan kelapa Gambar 5. menjelaskan bahwa tutupan hutan DAS Wosi Tahun 2006 2012 tidak mengalami perubahan kemudian mengalami penurunan sebesar $1.34 \%$ pada periode Tahun 2012 - 2015 . Penurunan tutupan hutan tersebut disebabkan terjadinya pembukaan hutan menjadi lahan terbuka untuk persiapan pemukiman. Berdasarkan analisis wilayah DAS dan Peta Kawasan Hutan, DAS Wosi didominasi oleh Areal Bukan Kawasan Hutan atau Areal Penggunaan Lain yang diperuntukan untuk kepentingan pengembangan wilayah dan pembangunan daerah.

Hasil analisis lanjutan terhadap tutupan lahan Tahun 2006 dan Tahun 2016, deforestasi pada ketiga DAS tersebut mempunyai karakteristik yang hampir sama. Deforestasi di DAS Arui sebagai akibat dari perubahan tutupan Hutan menjadi Semak Belukar sebesar 556.87 hektar (2.40\%), Hutan menjadi sawit milik PT. Medcopapua Hijau Selaras dan milik warga setempat. Pada Tahun 2012 PT. Medcopapua Hijau Selaras memperoleh Surat Keputusan Menteri Kehutanan tentang Pelepasan Kawasan Hutan Produksi yang dapat diKonversi seluas 6,791.24 hektar untuk budidaya perkebunan kelapa sawit yang terletak di Distrik Prafi, Masni, Sidey Lahan Terbuka sebesar 462.85 hektar (1.99 \%), dan Hutan menjadi Perkebunan sebesar 75.84 hektar $(0.33 \%)$. Deforestasi di DAS Prafi sebagai akibat dari perubahan tutupan Hutan menjadi Perkebunan sebesar 942.99 hektar (1.40 $\%$ ), Hutan menjadi Semak Belukar 251.74 hektar ( $0.37 \%$ ), dan Hutan menjadi Pertanian Lahan Kering Campur Semak 23.33 hektar $(0.03 \%)$. Deforestasi di DAS Wosi seluruhnya sebagai akibat dari perubahan tutupan Hutan menjadi Semak Belukar sebesar 31.54 hektar $(1.34 \%)$.

Selama Tahun 2006 - 2016, rata - rata deforestasi pada DAS Arui sebesar 109.65 hektar/tahun, DAS Prafi 121.80 hektar/tahun, dan DAS Wosi 3.16 hektar/tahun. Deforestasi pada ketiga DAS tersebut lebih kecil jika dibandingkan rata-rata deforestasi Provinsi Papua Barat Tahun 2013 -2016 yang mencapai 3,017.5 hektar/tahun 
(Direktorat Inventarisasi dan Pemantauan Sumber Daya Hutan, 2015; Kementerian Lingkungan Hidup dan Kehutanan, 2017).

\section{Degradasi Hutan}

Degradasi hutan yang terjadi pada Tiga DAS, Arui, Prafi, dan Wosi dapat dilihat pada Gambar 6.

Gambar 6 memperlihatkan degradasi hutan yang terjadi pada DAS Arui, Prafi dan Wosi selama kurun waktu Tahun 2006 - 2016. Secara luasan, degradasi hutan terbesar terjadi pada DAS Prafi, kemudian DAS Arui, dan DAS Wosi, namun presentase degradasi hutan terbesar terjadi di DAS Wosi (39.00\%), kemudian di DAS Arui (8.16\%), dan terakhir DAS Prafi (3.10 $\%)$. Penyebab utama degradasi hutan adalah kegiatan pemanenan hasil hutan kayu/penebangan kayu baik yang dilakukan secara legal melalui mekanisme perizinan yang sah atau dilakukan secara illegal. Hasil analisis lanjutan pada DAS Prafi terlihat bahwa degradasi hutan terbesar terjadi pada Kawasan Hutan Lindung berakses tinggi yang berada pada daerah Hulu DAS. Daerah yang mengalami degradasi hutan berada pada jalan raya dan pemukiman yang sangat terbuka bagi akses kegiatan penebangan secara illegal dalam kawasan Hutan Lindung. Hal ini sejalan dengan hasil kajian FWI/GFW (2001), bahwa batas-batas kawasan lindung ternyata merupakan pertahanan yang lemah dari serangan pembalakan ilegal, perambahan untuk kegiatan pertanian dan perburuan liar yang berlangsung di kebanyakan hutan-hutan Indonesia. Pemukiman dan penebangan hutan ilegal berlangsung secara terbuka dan bahkan di kawasan-kawasan lindung.

Pada DAS Arui, degradasi hutan terbesar terjadi pada Kawasan Hutan Produksi Terbatas pada daerah hulu DAS dan Hutan Produksi yang dapat diKonversi pada daerah hilir DAS. Degradasi hutan yang terjadi di DAS Arui diduga disebabkan oleh kegiatan penebangan kayu oleh masyarakat setempat baik secara legal melalui Izin Pemungutan Hasil Hutan Kayu (IPHHK) maupun yang dilakukansecara illegal. DAS Wosi mengalami degradasi hutan yang paling kecil. Hal ini disebabkan karena luas Hutan Primer di DAS Wosi pada Tahun 2006 hanya tersisa 136.29 hektar $(5.81 \%)$ dari luas DAS. Degradasi hutan pada DAS Wosi terjadi pada kawasan Hutan Produksi yang dapat diKonversi yang berada pada daerah hulu DAS.

Secara spasial deforestasi dan degradasi hutan di DAS Arui, DAS Prafi, dan DAS Wosi Tahun 2006 dan 2016 dapat dilihat pada Lampiran 3 - 5.

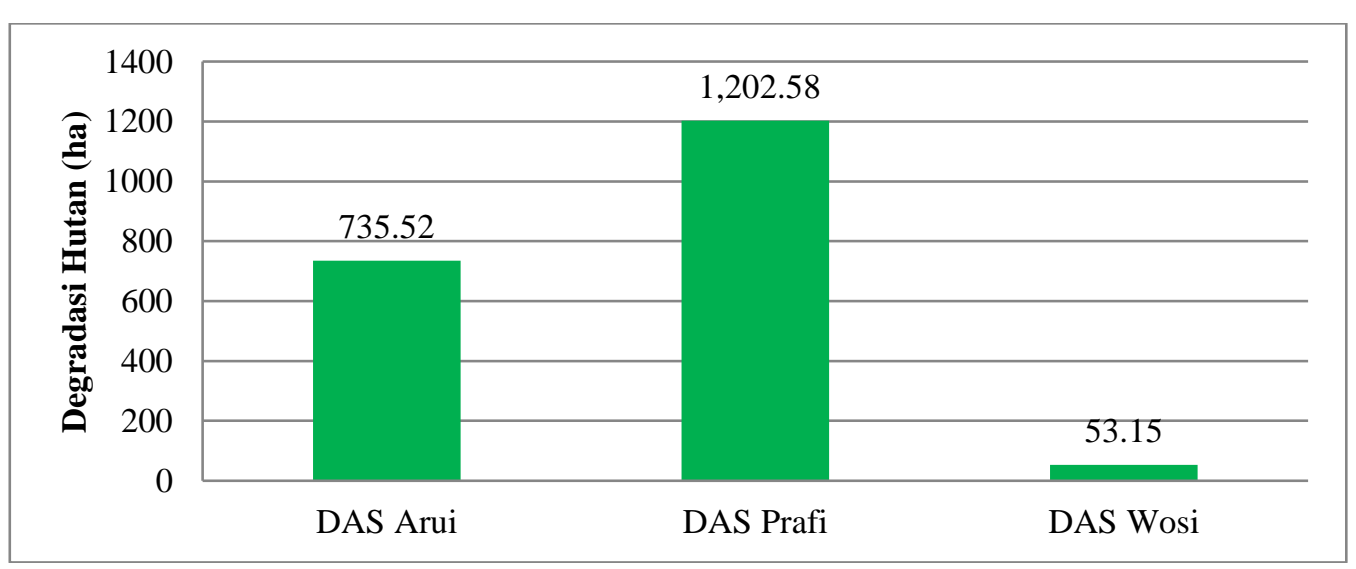

Gambar 6. Degradasi Hutan pada Tiga DAS, Arui, Prafi, dan Wosi Tahun 2006 - 2016 
Faktor-Faktor yang Mempenga-ruhi Perubahan Kawasan Hutan dan Tutupan Hutan pada Tiga DAS, Arui, Prafi, dan Wosi.

\section{Faktor yang Mempengaruhi Peru- bahan Kawasan Hutan}

Kawasan hutan secara de jure ditetapkan dengan Keputusan Menteri Kehutanan sehingga perubahan peruntukan kawasan hutan menjadi bukan kawasan hutan hanya dapat dilakukan atau ditetapkan oleh Menteri Lingkungan Hidup dan Kehutanan atas dasar permohonan. Sesuai Peeraturan Pemerintah Nomor 104 Tahun 2015 tentang Tata Cara Perubahan Peruntukan dan Fungsi Kawasan Hutan Pasal 6 bahwa Perubahan Peruntukan Kawasan Hutan dapat dilakukan Secara Parsial atau Untuk wilayah Provinsi. Selanjutnya dijelaskan bahwa perubahan peruntukan kawasan hutan secara parsial dilakukan melalui Tukar Menukar Kawasan Hutan atau Pelepasan Kawasan Hutan Produksi yang dapat Dikonversi. Perubahan Peruntukan Kawasan Hutan Untuk Wilayah Provinsi dapat dilakukan pada Kawasan Hutan Konservasi, Hutan Lindung, dan Hutan Produksi yang diintegrasikan dalam revisi Rencana Tata Ruang Wilayah Provinsi.

Kawasan Hutan di Provinsi Papua Barat ditetapkan berdasarkan SK.Menteri Kehutanan Nomor: SK.783/ Menhut-II/2014 tentang Kawa-san Hutan dan Konservasi Perairan Provinsi Papua Barat yang ditetapkan berdasarkan usulan Revisi Rencana Tata Ruang Wilayah Provinsi Papua Barat Tahun 2013 - 2033 yang mengakomodir kebutuhan ruang untuk pengembangan wilayah, pembangunan dan investasi daerah. Perubahan Kawasan Hutan pada wilayah provinsi ini secara langsung juga mengakibatkan perubahan luas kawasan hutan pada skala DAS. Perubahan Luas Kawasan Hutan berdasarkan fungsi pada Tiga DAS, Arui, Prafi dan Wosi dapat dilihat pada Tabel 5., Tabel 6., dan Tabel 7.

Tabel 5. menunjukan bahwa terjadi pengurangan total luas kawasan hutan DAS Arui sebesar 2.613.36 hektar dari 14,067.86 hektar sesuai SK.891/Menhutbun-II/1999 menjadi 11,454.52 hektar sesuai SK.783/MenhutII/2014. Pengurangan terbesar terjadi pada Fungsi Kawasan Hutan Produksi yang dapat diKonversi sebesar 1,637.69 hektar, kemudian Kawasan Suaka Alam sebesar 211.52 hektar dan Hutan Produksi Terbatas 764.15 hektar. Tabel 5 juga memperlihatkan bahwa keseluruhan pengurangan luas kawasan hutan tersebut dirubah peruntukannya menjadi bukan kawasan hutan atau Areal Penggunaan Lain yang mengalami penambahan luas 2,613.36 hektar. Dari total pengurangan luas kawasan hutan pada DAS Arui, 1,177.76 hektar merupakan perubahan peruntukan kawasan hutan secara parsial melalui pelepasan Kawasan Hutan Produksi yang dapat diKonversi untuk areal perkebunan kelapa sawit a.n. PT. Medcopapua Hijau Selaras. Sisanya sebesar 1,435.60 hektar merupakan perubahan peruntukan akibat perubahan Rencana Tata Ruang Wilayah Provinsi Papua Barat dan Kabupaten Manokwari Tahun 2013 - 2033.

Tabel 6 menunjukan bahwa terjadi pengurangan total luas kawasan hutan DAS Prafi sebesar 6,834.18 hektar dari 55,220.30 hektar sesuai SK.891/ Menhutbun-II/1999 menjadi 48,386.12 hektar sesuai SK.783/Menhut-II/2014. Pengurangan luas kawasan hutan terbesar terjadi pada Fungsi Kawasan Hutan Produksi yang dapat diKonversi sebesar 4,485.18 hektar, diikuti Hutan Produksi Terbatas 3,003.32 hektar, dan 
Hutan Produksi (HP) 55.58 hektar. Hal menarik pada DAS Prafi, bahwa selain terjadi pengurangan luas fungsi kawasan hutan, juga terdapat fungsi kawasan hutan yang mengalami penambahan luasan yaitu Kawasan Suaka Alam sebesar 403.09 hektar dan Hutan Lindung sebesar 307.29 hektar. Berdasarkan Tabel 6 juga terlihat bahwa keseluruhan pengurangan luas kawasan hutan dirubah peruntukannya menjadi bukan kawasan hutan/Areal Penggunaan Lain (APL) yang mengalami penambahan luas 6,834.18 hektar. Dari total pengurangan luas kawasan hutan pada DAS Prafi, 3,604.51 hektar merupakan perubahan peruntukan kawasan hutan secara parsial melalui pelepasan Kawasan Hutan Produksi yang dapat diKonversi untuk areal perkebunan kelapa sawit a.n. PT. Medcopapua Hijau Selaras. Sisanya sebesar 3,229.67 hektar merupakan perubahan peruntukan kawasan hutan akibat perubahan Rencana Tata Ruang Wilayah Provinsi Papua Barat dan Kabupaten Manokwari Tahun 2013 - 2033.

Tabel 7. menunjukan bahwa terjadi pengurangan total luas kawasan hutan DAS Wosi sebesar 404.62 hektar dari
751.75 hektar sesuai SK.891/Menhut bun-II/1999 menjadi 347.13 hektar sesuai SK.783/Menhut-II/2014. Pengurangan luas fungsi kawasan hutan tersebut seluruhnya terjadi pada Hutan Produksi yang dapat diKonversi. Pengurangan luas kawasan hutan pada DAS Wosi dirubah perun-tukannya menjadi bukan kawasan hutan/Areal Penggunaan Lain (APL) yang mengalami penambahan luas 404.62 hektar. Perubahan peruntukan tersebut merupakan akibat perubahan Rencana Tata Ruang Wilayah Provinsi Papua Barat dan Kabupaten Manokwari Tahun 2013 - 2033 yang mengakomodir kebutuhan daerah khususnya Kabupaten Manokwari untuk pengembangan wila-yah dan pemukiman. DAS Wosi meliputi Distrik Manokwari Barat dan Distrik Manokwari Selatan yang merupakan Ibu Kota Kabupaten Manok-wari dan pusat pemerintahan Provinsi Papua Barat serta merupkan pusat perekonomian yang mengalami pertum-buhan wilayah yang pesat. Keadaan ini menuntut tersedianya lahan yang cukup dan legal sehingga Kawasan Hutan yang ada dirubah peruntukannya menjadi Areal Penggunaan Lain.

Tabel 5. Perubahan Luas Kawasan Hutan berdasarkan fungsi pada DAS Arui

\begin{tabular}{lrrrrr}
\hline \multirow{2}{*}{ Fungsi Kawasan } & \multicolumn{2}{c}{ SK.891/1999 } & \multicolumn{2}{c}{ SK.783/2014 } & \multicolumn{1}{c}{$\begin{array}{c}\text { Perubahan } \\
\text { (ha) }\end{array}$} \\
\cline { 2 - 6 } & \multicolumn{1}{c}{ Luas (ha) } & \% & Luas (ha) & \multicolumn{1}{c}{$\%$} & \multicolumn{1}{c}{} \\
\hline Kawasan Hutan & $\mathbf{1 4 , 0 6 7 . 8 6}$ & $\mathbf{6 0 . 5 4}$ & $\mathbf{1 1 , 4 5 4 . 5 2}$ & $\mathbf{4 9 . 3}$ & $-\mathbf{2 , 6 1 3 . 3 6}$ \\
Hutan Konservasi & 215.98 & 0.93 & 4.46 & 0.02 & -211.52 \\
Hutan Lindung & 182.07 & 0.78 & 182.07 & 0.78 & - \\
Hutan Produksi Terbatas & $9,830.24$ & 42.31 & $9,066.09$ & 39.02 & -764.15 \\
Hutan Produksi Konversi & $3,839.57$ & 16.52 & $2,201.90$ & 9.48 & $-1,637.69$ \\
Areal Pengunaan Lain & $\mathbf{9 , 1 3 4 . 0 9}$ & $\mathbf{3 9 . 3 1}$ & $\mathbf{1 1 , 7 4 7 . 4 2}$ & $\mathbf{5 0 . 5 6}$ & $\mathbf{2 , 6 1 3 . 3 3}$ \\
Tubuh Air & $\mathbf{3 3 . 2 9}$ & $\mathbf{0 . 1 4}$ & $\mathbf{3 3 . 2 9}$ & $\mathbf{0 . 1 4}$ & - \\
\hline Jumlah & $\mathbf{2 3 , 2 3 5 . 2 4}$ & $\mathbf{1 0 0}$ & $\mathbf{2 3 , 2 3 5 . 2 3}$ & $\mathbf{1 0 0}$ & - \\
\hline
\end{tabular}


Tabel 6. Perubahan Luas Kawasan Hutan berdasarkan fungsi pada DAS Prafi

\begin{tabular}{lrrrrr}
\hline \multirow{2}{*}{\multicolumn{1}{c}{ Fungsi Kawasan }} & \multicolumn{2}{c}{ SK.891/1999 } & \multicolumn{2}{c}{ SK.783/2014 } & \multirow{2}{*}{$\begin{array}{c}\text { Perubahan } \\
\text { (ha) }\end{array}$} \\
\cline { 2 - 5 } & Luas (ha) & \multicolumn{1}{c}{$\%$} & Luas (ha) & \multicolumn{1}{c}{$\%$} & \multicolumn{1}{c}{} \\
\hline Kawasan Hutan & $\mathbf{5 5 , 2 2 0 . 3 0}$ & $\mathbf{8 1 . 7 3}$ & $\mathbf{4 8 , 3 8 6 . 1 2}$ & $\mathbf{7 1 . 6 2}$ & $\mathbf{- 6 , 8 3 4 . 1 8}$ \\
Hutan Konservasi & $7,941.34$ & 11.75 & $8,344.43$ & 12.35 & 403.09 \\
Hutan Lindung & $19,179.96$ & 28.39 & $19,487.25$ & 28.85 & 307.29 \\
Hutan Produksi Terbatas & $17,331.30$ & 25.65 & $14,327.98$ & 21.21 & $-3,003.32$ \\
Hutan Produksi Tetap & $4,099.20$ & 6.07 & $4,043.32$ & 5.98 & -55.88 \\
Hutan Produksi Konversi & $6,668.50$ & 9.87 & $2,183.14$ & 3.23 & $-4,485.36$ \\
Areal Penggunaan Lain & $\mathbf{1 2 , 0 6 0 . 8 6}$ & $\mathbf{1 7 . 8 5}$ & $\mathbf{1 8 , 8 9 5 . 0 4}$ & $\mathbf{2 7 . 9 7}$ & $\mathbf{6 , 8 3 4 . 1 8}$ \\
Tubuh Air & $\mathbf{2 7 6 . 8}$ & $\mathbf{0 . 4 1}$ & $\mathbf{2 7 6 . 8}$ & $\mathbf{0 . 4 1}$ & $\mathbf{0 . 0 0}$ \\
\hline Jumlah & $\mathbf{6 7 , 5 5 7 . 9 6}$ & $\mathbf{1 0 0 . 0 0}$ & $\mathbf{6 7 , 5 5 7 . 9 6}$ & $\mathbf{1 0 0 . 0 0}$ & - \\
\hline
\end{tabular}

Tabel 7. Perubahan Luas Kawasan Hutan berdasarkan fungsi pada DAS Wosi

\begin{tabular}{lccccr}
\hline \multirow{2}{*}{ Fungsi Kawasan } & \multicolumn{2}{c}{ SK.891/1999 } & \multicolumn{2}{c}{ SK.783/2014 } & \multicolumn{2}{c}{ Perubahan } \\
\cline { 2 - 5 } \multicolumn{1}{c}{ Luas } & \multicolumn{1}{c}{$\%$} & \multicolumn{1}{c}{ Luas } & \multicolumn{1}{c}{$\boldsymbol{\text { (ha) }}$} \\
\hline Kawasan Hutan & $\mathbf{7 5 1 . 7 5}$ & $\mathbf{3 2 . 0 4}$ & $\mathbf{3 4 7 . 1 3}$ & $\mathbf{1 4 . 7 9}$ & $\mathbf{4 0 4 . 6 2}$ \\
Hutan Produksi Konversi & 751.75 & 32.04 & 347.13 & 14.79 & 404.62 \\
Areal Penggunaan Lain & $\mathbf{1 , 5 9 4 . 5 6}$ & $\mathbf{6 7 . 9 6}$ & $\mathbf{1 , 9 9 9 . 1 9}$ & $\mathbf{8 5 . 2 1}$ & $\mathbf{4 0 4 . 6 2}$ \\
\hline Jumlah & $\mathbf{2 , 3 4 6 . 3 1}$ & $\mathbf{1 0 0 . 0 0}$ & $\mathbf{2 , 3 4 6 . 3 2}$ & $\mathbf{1 0 0 . 0 0}$ & - \\
\hline
\end{tabular}

Faktor-Faktor yang Mempenga-ruhi Perubahan Tutupan Hutan

Berdasarkan berbagai referensi penyebab terjadinya perubahan tutupan hutan (deforestasi), faktor-faktor yang relevan sebagai penyebab terjadinya deforestasi pada tiga DAS, Arui, Prafi, dan Wosi adalah pertambahan jumlah penduduk dan investasi perusahaan perkebunan kelapa sawit.

\section{Pertambahan Jumlah Pendu-duk}

Berdasarkan pembagian wilayah administrativ, DAS Arui mencakup Distrik Masni dan Distrik Prafi, DAS Prafi mencakup Distrik Prafi, Distrik Masni, dan Distrik Warmare Kabupaten Manokwari dan Distrik Menyambouw Kabupaten Pegunungan Arfak, sedangkan DAS Wosi mencakup Distrik Manokwari Barat dan Distrik Manokwari Selatan. Data dari BPS Kabupaten Manokwari Tahun 2017, memperlihatkan bahwa jumlah penduduk yang berada pada Distrik-Distrik di ketiga DAS tersebut meningkat sejak Tahun 2006. Jumlah Penduduk yang berada di DAS Arui, DAS Prafi dan DAS Wosi Tahun 2006 dan Tahun 2016 dapat dilihat pada Gambar 7.

Gambar 7. memberikan gambaran jumlah penduduk di distrik-distrik yang berada pada DAS Arui, DAS Prafi, dan DAS Wosi yang cenderung meningkat sejak Tahun 2006. Peningkatan jumlah penduduk tertinggi terjadi di DAS Wosi (68,70\%), diikuti oleh DAS Arui (19,68 $\%$ ), dan yang terendah di DAS Prafi $(15.52 \%)$. Secara teoritis pertambahan jumlah penduduk di ketiga DAS tersebut akan berpengaruh terhadap terjadinya deforestasi. Jumlah penduduk yang semakin meningkat akan meningkatkan kebutuhan akan ruang untuk pemukiman dan lahan untuk pertanian dalam rangka pemenuhan kebutuhan pangan. Tekanan penduduk untuk kebutuhan ruang dan 
lahan ini akan mendorong terjadinya pembukaan hutan sehingga mengakibatkan terjadinya deforestasi. Sunderlin dan Resosudarmo (1997) menegaskan bahwa pertambahan penduduk di pedesaan Indonesia ikut memegang peranan dalam deforestasi. Sejalan dengan itu, Paimin et $a l .$, (2012) menyatakan bahwa faktor yang mengakibatkan perubahan penutupan hutan antara lain pertambahan penduduk dan pembangunan di luar sektor kehutanan yang sangat pesat memberi pengaruh besar terhadap meningkatnya kebutuhan lahan hutan dan produk-produk dari hutan.

Fraser (1996) dalam Sunderlin dan Resosudarmo (1997) mengemukakan bahwa pertumbuhan kepadatan penduduk merupakan penjelasan fundamental akan masalah deforestasi di Indonesia. Pada tiap $1 \%$ kenaikan penduduk (kenaikan penduduk di pulau-pulau di luar pulau Jawa adalah 3\%) terjadi penurunan kirakira 0,3\% tutupan hutan. Angelsen (1995) dalam Sunderlin dan Resosudarmo (1997) dengan studi kasus Sumatera memberikan gambaran yang lebih konservatif bahwa pertumbuhan jumlah penduduk menjelaskan kira-kira seperempat dari hilangnya tutupan hutan.

Hasil penelitian pada skala DAS yang dilakukan Prasetyo (2004) pada DAS Citanduy, Jawa Barat memperlihatkan korelasi negative antara pertambahan penduduk dan penurunan luas tutupan hutan, semakin tinggi kepadatan penduduk di kecamatan dalam wilayah DAS, maka konversi hutan menjadi peruntukan lain cenderung lebih cepat. Hasil-hasil penelitian tersebut sejalan dengan argumentasi yang yang dikemukakan oleh Todaro dan Smith (2004), bahwa salah satu konsekuensi negative dari pertumbuhan penduduk yang pesat adalah terhadap lingkungan hidup. Pertumbuhan penduduk yang pesat akan ikut memacu proses kerusakan dan pengrusakan lingkungan hidup, baik itu berupa penggundulan hutan, pengikisan cadangan bahan bakat kayu, erosi tanah, penyusutan populasi ikan dan hewanhewan liar, pencemaran air, pencemaran udara, dan pemadatan daerah hunian di perkotaan.

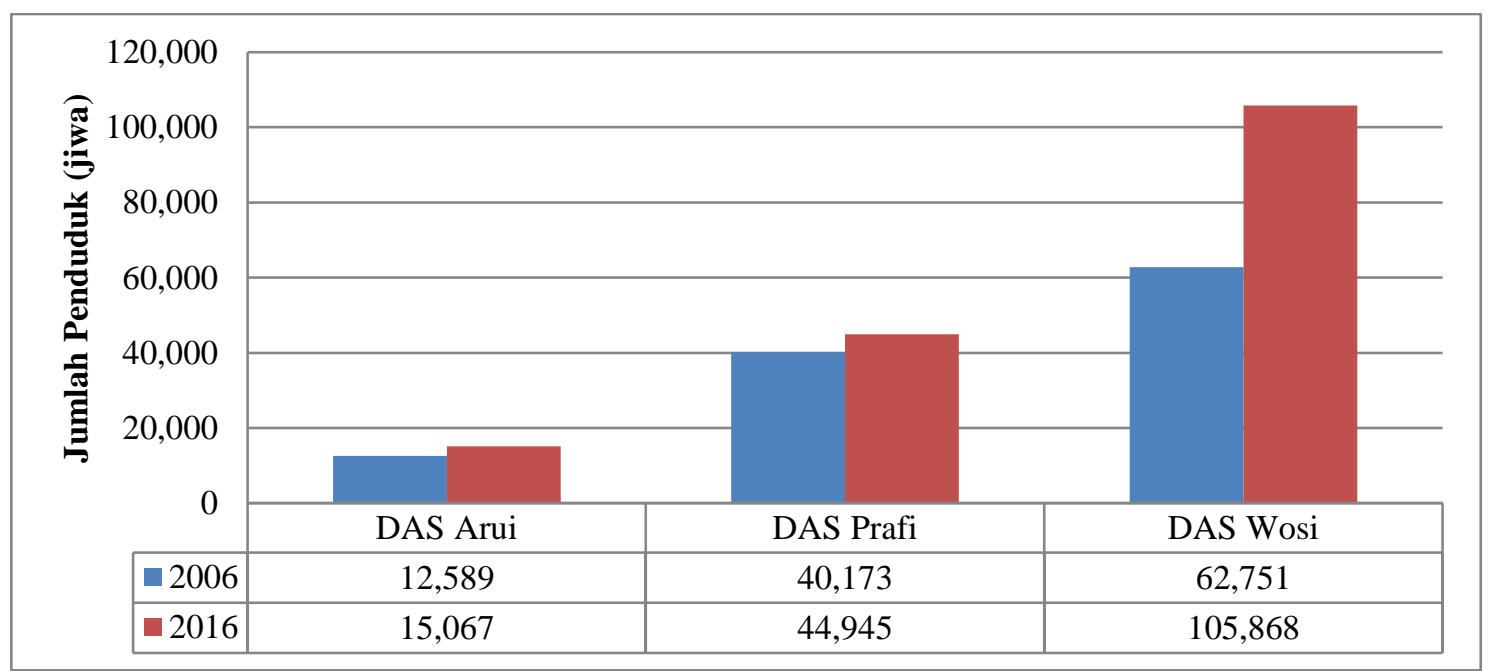

Gambar 7. Jumlah Penduduk di Wilayah Tiga DAS, Arui, Prafi, dan Wosi 
Tabel 8. Perkembangan Investasi Perkebunan Kelapa Sawit pada Tiga DAS, Arui, Prafi dan Wosi

\begin{tabular}{ccccc}
\hline \multirow{2}{*}{ DAS } & \multicolumn{2}{c}{ Tahun 2006 } & \multicolumn{2}{c}{ Tahun 2016 } \\
\cline { 2 - 5 } & Jumlah & Luas (ha) & Jumlah & Luas (ha) \\
\hline Arui & 1 & $3,520.29$ & 2 & $4,698.05$ \\
Prafi & 1 & $5,744.97$ & 2 & $9,349.47$ \\
Wosi & - & - & - & - \\
\hline
\end{tabular}

\section{Investasi Perusahaan Perke-bunan Kelapa Sawit}

Investasi perkebunan skala besar khususnya perkebunan kelapa sawit merupakan salah satu penyebab terjadinya deforestasi di Indonesia (Sunderlin dan Resosudarmo ( 1997). Investasi perkebunan kelapa sawit di Kabupaten Manokwari dimulai sejak Tahun 1992 dengan masuknya PT. Perkebunan Nusantara II di Distrik Warmare, Distrik Prafi dan Distrik Masni. Kawasan hutan yang dilepaskan seluas 17,817 hektar yang kemudian lahannya dialihkan kepada PT. Yong Jin Investment. Pada Tahun 2012 investasi perkebunan kelapa sawit di Kabupaten Manokwari bertambah dengan masuknya PT. Medcopapua Hijau Selaras yang memperoleh pelepasan kawasan Hutan Produksi yang dapat diKonversi seluas 6,791 hektar yang termasuk dalam DAS Arui dan DAS Prafi.

Hasil analisis spasial menunjukan bahwa pada DAS Prafi deforestasi yang terjadi berada di dalam dan sekitar areal usaha perkebunan kelapa sawit. Hal ini dapat terjadi karena perkebunan akan melakukan pembersihan lahan (land clearing) dengan menebang habis seluruh vegetasi yang ada dan menggantinya dengan tanaman perkebunan. Perubahan peruntukan kawasan hutan dari Hutan Produksi yang dapat diKonversi menjadi Bukan Kawasan Hutan/Areal Penggunaan Lain khususnya untuk investasi perkebunan sangat berperan terhadap terjadinya deforestasi.
Kondisi ini juga terjadi pada Areal Penggunaan Lain dalam areal perkebunan kelapa sawit PT. Medcopapua Hijau Selaras.

\section{KESIMPULAN}

1. Sampai dengan Tahun 2016, persentase luas kawasan hutan terhadap total DAS untuk dua DAS (Arui dan Prafi) masih di atas $30 \%$, sedangkan DAS Wosi hanya 14.79 $\%$, akan tetapi persentase luas tutupan hutan untuk ketiga DAS tersebut masih di atas $30 \%$. Komposisi Kawasan Hutan dari DAS Arui dan Prafi didominasi oleh Hutan Tetap, sebaliknya DAS Wosi didominasi oleh Hutan Produksi yang dapat dikonversi. Pada dua DAS (Arui dan Prafi), distribusi kawasan hutannya lebih terkonsentrasi pada daerah hulu dengan hutan primer lebih dominan, sedangkan DAS Wosi hanya pada sebagian daerah hulu dengan dominasi hutan sekunder.

2. Selama Tahun 2006 - 2016, deforestasi terbesar terjadi pada DAS Arui (4.71 \%; 121,80 hektar/tahun), sebaliknya degradasi hutan tertinggi terjadi pada DAS Wosi (39\%; 5.31 hektar/tahun). Laju deforestasi pada tiga DAS tersebut masih jauh dibawa rata-rata laju deforestasi Provinsi Papua Barat yang mencapai 3,017.50 hektar/tahun.

3. Faktor dominan penyebab terjadinya perubahan kawasan pada Tiga DAS, 
adalah faktor perubahan peruntukan kawasan hutan secara parsial dan untuk Wilayah Provinsi melalui Perubahan Rencana Tata Ruang Wilayah Provinsi Papua Barat dan Kabupaten Manokwari Tahun 2013 - 2033, sedangkan untuk deforestasi adalah faktor pertambahan jumlah penduduk, dan faktor konversi lahan menjadi areal perkebunan kelapa sawit milik perusahaan dan masyarakat setempat.

\section{DAFTAR PUSTAKA}

Asdak., C. 2014. Hidrologi dan Pengelolaan Daerah Aliran Sungai. Cetakan kelima (revisi). Gadjah Mada University Press. Yogyakarta.

BPS Kabupaten Manokwari. 2016. Kabupaten Pegunungan Arfak dalam Angka Tahun 2016. Manokwari

BPS Kabupaten Manokwari. 2017. Kabupaten Manokwari dalam Angka Tahun 2017. Manokwari

Direktorat Inventarisasi dan Pemantauan Sumber Daya Hutan. 2015. Deforestasi Indonesia Tahun 2012 2013. Kementerian Lingkungan Hidup dan Kehutanan. Jakarta.

FWI/GFW. 2001. Keadaan Hutan Indonesia. Indonesia: Forest Watch Indonesia dan Washington D.C.: Global Forest Watch. Bogor.

https://manokwarikab.bps.go.id/dynamic table/2016/03/22/58/pendudukdirinci-menurut-distrik-tahun-2005--2015.html [Diakses Februari 2018]

Iskandar, Silalahi, M. D., Hasan, D., dan Nurlinda, I. 2011. Kebijakan Perubahan Kawasan Hutan dalam
Pengelolaan Berkelanjutan. UNPAD Press. Bandung.

Kadir, S. 2015. Penutupan Lahan untuk Pengendalian Tingkat Kekritisan DAS Satui,Provinsi Kalimantan Selatan. Proseding Seminar Nasional Masyarakat Biodiversity Indonesia. Volume 1, Nomor 3, Juni 2015.

Khasanah K, Mulyoutami E, Ekadinata A, Asmawan T, Tanika L, Said Z, van Noordwijk M, and Leimona B. 2010. Kaji Cepat Hidrologi di Daerah Aliran Sungai Krueng Peusangan, NAD, Sumatra. Working paper nr.122. Bogor, Indonesia. World Agroforestry Centre.55p. DOI $10.5716 / \mathrm{WP} 10$ 337.

Maryani, R., Iis, A., Wicaksono D., Suka, A. P., hakim, I., Rohmanudin, J., dan Effendi, R. 2014. Sintesis Riset Integratif. Manajemen Lanskap Hutan Berbasis DAS. Pusat Penelitian dan Pengembangan Perubahan Iklim dan Kebijakan Kementerian Lingkungan Hidup dan Kehutanan. Bogor.

Mulyana, N. 2012. Analisis Luas Tutupan Hutan terhadap Ketersediaan Green Water dan Blue Water di Sub Das Gumbasa dan Sub Das Cisadane Hulu dengan Aplikasi Model Swat. Disertasi. Sekolah Pasca Sarjana IPB Bogor.

Paimin, Pramono, I. B., Purwanto, dan Indrawati D. R. 2012. Sistem Perencanaan Pengelolaan Daerah Aliran Sungai. Pusat Penelitian dan Pengembangan Konservasi dan Rehabilitasi (P3KR). Kementerian Kehutanan. Bogor 
Peraturan Pemerintah RI Nomor 44 Tahun 2004 tentang Sistem Perencanaan Kehutanan.

Peraturan Pemerintah RI Nomor 28 Tahun 2011 tentang Pengelolaan Kawasan Suaka Alam dan Kawasan Pelestarian Alam.

Peraturan Pemerintah RI Nomor 37 Tahun 2012 tentang Pengelolaan Daerah Aliran Sungai.

Peraturan Pemerintah RI Nomor 104 Tahun 2015 tentang Tata Cara Perubahan Peruntukan dan Fungsi Kawasan Hutan.

Pramono, I. B., dan Wahyuningrum N. 2010. Luas Optimal Hutan Jati sebagai Pengatur Tata Air di Daerah Aliran Sungai (DAS) Berbahan Induk Kapur. Jurnal Lit.HKA. Vol VII. No.5. Bogor

Pramono, I.B., dan Wijaya, W. W. 2013. Hubungan antara Hutan Pinus dan Aliran Dasar di Sub DAS Kedung Bulus, Kebumen. Prosiding Seminar Nasional Hasil Penelitian Teknologi Pengelolaan DAS. Pusat Penelitian dan Pengembangan Konservasi dan Rehabilitasi (P3KR). Surakarta.

Prasetyo, L.B. 2004. Deforstasi dan Degradasi Lahan DAS Citanduy. Pusat Studi Pembanguan, IPB. Bogor.

Sunandar, A. D. 2014. Penentuan Luas Hutan Optimal Ditinjau dari Respon Hidrologis di DAS Asahan. Disertasi. Sekolah Pasca Sarjana IPB Bogor.

Sunderlin, W. D., dan Resosudarmo I. A. P., 1997. Laju dan Penyebab
Deforestasi di Indonesia: Penelaahan Kerancuan dan Penyebabnya. Occasional Paper No. 9 (i). CIFOR. Bogor

Todaro, M.P dan Simith, S.C 2004. Pembangunan Ekonomi di Dunia Ketiga. Edisi Kedelapan. Alih Bahasa: Haris Mundandar, Puji, A.L. Editor: Wisnu C. Kritiaji. Jilid 1. Erlangga. Jakarta

Undang-Undang RI Nomor 41 Tahun 1999 tentang Kehutanan.

Wibowo, A., dan Ginting N.,A., 2010. Degradasi dan Upaya Pelestarian Hutan. Membalik Kecenderungan Degradasi Sumber Daya Lahan dan Air. IPB Press. Bogor. 